\title{
Efficacy of Cow Urine as Plant Growth Enhancer and Antifungal Agent
}

\author{
Savita Jandaik, ${ }^{1}$ Preeti Thakur, ${ }^{2}$ and Vikas Kumar ${ }^{2}$ \\ ${ }^{1}$ Shoolini University of Biotechnology and Management Sciences, Solan, Himachal Pradesh 173212, India \\ ${ }^{2}$ Shoolini Institute of Life Sciences and Business Management, Solan, Himachal Pradesh 173212, India \\ Correspondence should be addressed to Savita Jandaik; drsavitajandaik@gmail.com
}

Received 7 July 2015; Revised 7 October 2015; Accepted 8 October 2015

Academic Editor: Tibor Janda

Copyright (C) 2015 Savita Jandaik et al. This is an open access article distributed under the Creative Commons Attribution License, which permits unrestricted use, distribution, and reproduction in any medium, provided the original work is properly cited.

\begin{abstract}
The present study was conducted to determine antifungal activity of three different concentrations $(5,10$, and $15 \%)$ of cow urine against three fungal pathogens (Fusarium oxysporum, Rhizoctonia solani, and Sclerotium rolfsii) isolated from infected plants of Methi and Bhindi that showed symptoms of damping off and wilting disease by poison food technique. The extent of growth of test fungi in plates poisoned with cow urine was lesser when compared with the control plates. Among these concentrations cow urine at $15 \%$ concentration was most effective. When the three fungal organisms were compared, maximum growth suppression was observed in Fusarium oxysporum (78.57\%) at 15\% concentration of cow urine followed by Rhizoctonia solani (78.37\%) and Sclerotium rolfsii (73.84\%). Finally we concluded that the cow urine has antifungal activities and the inhibitory activity can be used in the control of fungi. The nutritional effect of cow urine on plant growth was also tested with Trigonella foenum-graecum (Methi) and Abelmoschus esculentus (Bhindi) plants and the chlorophyll and protein content was also estimated.
\end{abstract}

\section{Introduction}

Vegetable plants suffer from diseases caused by various kinds of pathogens such as bacteria, fungi, viruses, nematodes, and mycoplasma. Among these, fungi are considered as most aggressive pathogens causing qualitative and quantitative damage. Fungal pathogens, namely, Fusarium oxysporum, Rhizoctonia solani, and Sclerotium rolfsii, are associated with damping off and wilting of Methi and Bhindi (Okra). The plant diseases have significant role in agriculture in terms of reduction of yield and economy. One of the most widely used strategies to control plant diseases is the use of chemical agents. However, overuse and abuse of these chemical agents resulted in certain hazardous effects. These chemicals suffer from drawbacks such as high cost, toxicity to nontarget organisms, residual problem, and development of resistance in pathogens. This situation triggered interest in searching alternates for disease control. Natural products, in particular from plants, can be the potential candidates which can be used against phytopathogenic fungi. The use of these agents is risk-free when compared to synthetic chemicals.
In ancient Ayurveda cow urine has been greatly mentioned for its pharmacological importance. Okra contains nutrients that may confer a number of health advantages, including a decreased risk of several serious medical problems. Methi is one of the oldest medicinal herbs; ongoing research in India and abroad is currently uncovering new possibilities for its potential role in the treatment of diabetes and high cholesterol levels associated with coronary heart disease, both of which plague many industrial societies [1]. Cow urine is one of the ingredients of "Panchagavya" (urine, dung, milk, curd, and ghee) which is capable of treating many diseases as it has several medicinal properties [2] and it is the best remedy to cure fungal and bacterial diseases. It has an excellent germicidal power, antibiotics and antimicrobial activity. Therefore, cow urine can kill varieties of germs and it also boosts immunity [3]. Cow urine contains many beneficial elements, that is, chemical properties, potentialities, and constituents which help in removing all the ill effects and imbalances of body caused by infectious agents. Cow urine contains $95 \%$ water, $2.5 \%$ urea, and the remaining $2.5 \%$ a mixture of salts, hormones, enzymes, and minerals [4]. It has been considered 
that cow urine is very useful in agricultural operations as a biofertilizer and biopesticide [5] as it can kill number of pesticide and herbicide resistant bacteria, viruses, and fungi. Cow urine in combination with plant extracts is used to prepare disinfectant which is biodegradable and ecofriendly with good antibacterial action [6]. Majority of people in India use cow urine to get rid of various diseases due to its therapeutic values. Cow urine has several biological activities such as antioxidant, antidiabetic, antitumor, antiprotozoal, and molluscicidal [7-9].

\section{Materials and Methods}

2.1. Collection of Cow Urine. Fresh cow urine was collected in a sterile container from a local variety of cow. The urine was filtered through Whatman No. 1 filter paper to get rid of debris and precipitated material and was stored in airtight container at $4^{\circ} \mathrm{C}$ before use.

2.1.1. Isolation of Fungal Pathogens. Fusarium oxysporum, Rhizoctonia solani, and Sclerotium rolfsii were isolated from infected plants of Methi and Bhindi (Okra) that showed symptoms of damping off and wilting.

2.2. Antifungal Activity. The three concentrations (5\%, $10 \%$, and $15 \% \mathrm{v} / \mathrm{v}$ ) of cow urine were prepared. $10 \mathrm{~mL}$ of different concentrations of cow urine was amended in $10 \mathrm{~mL}$ of potato dextrose agar medium and mixed thoroughly by stirring. Control was maintained in which distilled water was used instead of cow urine. The medium was autoclaved and poured into sterilized Petri plates and left. The fungal discs of $5 \mathrm{~mm}$ diameter were taken from actively growing cultures by using cork borer and the discs were transferred aseptically on PDA plates poisoned with cow urine. Plates were incubated at 28 $\pm 2^{\circ} \mathrm{C}$ temperature in incubator for 7 days. After 7 days plates were observed and colony diameters were measured with the help of ruler [10]. The percent of inhibition was calculated using the following formula given by [11]:

Percent inhibition of mycelial growth (\%)

$$
I=\frac{100(C-T)}{C},
$$

where $I$ is inhibition percentage, $C$ is colony diameter in control plates, and $T$ is colony diameter in poisoned plates.

\subsection{Effect of Cow Urine on Plant Growth}

2.3.1. Collection of Seeds. The seeds of Trigonella foenumgraecum (Methi) and Abelmoschus esculentus (Bhindi) were purchased from the local market of Solan, Himachal Pradesh.

2.3.2. Pot Culture Experiment. The pot culture study was conducted to find out the effect of various concentrations of cow urine on growth of Methi and Bhindi plants. The seeds were soaked in water over night and then 5 seeds were sown in different pots filled with sterile garden soil. The garden soil was sterilized in an autoclave at $15 \mathrm{lbs}$ pressure for half an hour. The $\mathrm{pH}$ of the soil was adjusted to 7. Each pot was irrigated twice a day with different concentrations $(1 \%, 2 \%, 3 \%, 4 \%$, and $5 \%(\mathrm{v} / \mathrm{v}))$ of cow urine. In control pots, the seeds were irrigated with tap water instead of cow urine. When the plants grew randomly 3 seedlings from each treatment were uprooted without disturbing the root system and different parameters such as plant height, shoot and root length, number of leaves and branches, and leaf length and breadth were measured after 25 days to observe the plant growth.

2.3.3. Estimation of Protein. $10 \mathrm{mg}$ of coomassie brilliant blue G250 was mixed with $10 \mathrm{~mL}$ of $88 \%$ phosphoric acid and $45 \mathrm{~mL}$ of absolute alcohol. Then the mixture was diluted to $100 \mathrm{~mL}$ with distilled water. $1 \mathrm{gm}$ of fresh germinated seedlings (test seedlings) was ground in $20 \mathrm{~mL}$ of distilled water. It was filtered and filtrate was made up to $20 \mathrm{~mL}$. Then $0.1 \mathrm{~mL}$ of filtrated solution was added with $0.9 \mathrm{~mL}$ of water to which $2 \mathrm{~mL}$ of coomassie blue was added. The absorbance was read at $595 \mathrm{~nm}$. Same procedure was repeated for the seedlings that were treated with water as control [12].

2.3.4. Estimation of Carbohydrate. $2 \mathrm{gm}$ of anthrone was diluted in one liter of sulphuric acid and stored in dark bottle and labeled as anthrone reagent. $5 \mathrm{gm}$ of plant sample was collected from control plant and test plants separately and ground in $2 \mathrm{~mL}$ of $80 \%$ acetone. The homogenized solution was filtered. $1 \mathrm{~mL}$ of filtered solution was added with $5 \mathrm{~mL}$ of anthrone reagent. The solution was heated in water bath for 5 minutes. The OD was taken for the above mentioned sample(s) at $600 \mathrm{~nm}$. Standard of glucose was prepared by dissolving $100 \mathrm{mg}$ of glucose in $100 \mathrm{~mL}$ water [13]. The concentration of carbohydrate was calculated using the formula:

Concentration of test sample

$$
=\frac{\text { Absorbance of Test }}{\text { Absorbanceof Std. }} \times \text { Concentration of Std. }
$$

2.3.5. Estimation of Chlorophyll. Fresh leaves were collected from control plant and test plant separately and $1 \mathrm{gm}$ of leaves was weighed. The leaves were cut into small pieces and homogenized in a mortar and pestle with excess of acetone and then filtered using Whatman No. 1 filter paper. The filtrate was collected and made up to $100 \mathrm{~mL}$ with acetone. $5 \mathrm{~mL}$ of extract was transferred into $50 \mathrm{~mL}$ volumetric flask and diluted to $50 \mathrm{~mL}$ with $80 \%$ acetone. Absorbance was read at $645 \mathrm{~nm}$ and $663 \mathrm{~nm}$ using spectrophotometer [14]. The quantity of chlorophyll a, chlorophyll b, and total chlorophyll was calculated using the following formula:

$$
\begin{aligned}
& \text { Chlorophyll a }(\mathrm{mg} / \mathrm{g}) \\
& \quad=12.7\left(A_{663}\right)-2.69\left(A_{645}\right) \times \frac{V}{1000 \times w},
\end{aligned}
$$


TABle 1: Antifungal activity of cow urine by poison food technique.

\begin{tabular}{|c|c|c|c|c|}
\hline S. number & Fungal pathogen & Concentrations (\%) & Colony diameter $(\mathrm{mm})$ & Percent of inhibition (\%) \\
\hline \multirow{4}{*}{1} & \multirow{4}{*}{ Fusarium oxysporum } & 0 (control) & 84 & 0.0 \\
\hline & & 5 & 38 & 54.76 \\
\hline & & 10 & 22 & 73.80 \\
\hline & & 15 & 18 & 78.57 \\
\hline \multirow{4}{*}{2} & \multirow{4}{*}{ Rhizoctonia solani } & 0 (control) & 74 & 0.0 \\
\hline & & 5 & 38 & 48.60 \\
\hline & & 10 & 30 & 59.45 \\
\hline & & 15 & 16 & 78.37 \\
\hline \multirow{4}{*}{3} & \multirow{4}{*}{ Sclerotium rolfsii } & 0 (control) & 65 & 0.0 \\
\hline & & 5 & 29 & 55.38 \\
\hline & & 10 & 24 & 63.07 \\
\hline & & 15 & 17 & 73.84 \\
\hline
\end{tabular}

Chlorophyll b (mg/g)

$$
=22.9\left(A_{645}\right)-4.68\left(A_{663}\right) \times \frac{V}{1000 \times w},
$$

Total chlorophyll (mg/g)

$$
=20.2\left(A_{645}\right)+8.02\left(A_{663}\right) \times \frac{V}{1000 \times w},
$$

where $A$ is optical density, $V$ is final volume of $80 \%$ acetone $(\mathrm{mL})$, and $w$ is dry weight of sample taken $(\mathrm{g})$.

2.4. Statistical Analysis. The experiment was performed in triplicate. The results were represented as mean \pm standard deviation (SD) to facilitate the comparison of the data.

\section{Results}

In the present studies three fungal pathogens, namely, Fusarium oxysporium var. trifoli, Rhizoctonia solani Kuhn (Corticium Vagum B. \& C.), and Sclerotium rolfsii Sacc. were isolated from the diseased Trigonella foenum-graecum (Methi) and Abelmoschus esculentus (Bhindi) plants. Data presented in Table 1 depicts that all concentrations $(5,10$, and $15 \%$ ) of cow urine were effective against the growth of the fungus which exhibited the significant inhibition in the growth of fungal plant pathogens. With increase in concentration of cow urine there was corresponding increase in the inhibition of vegetative growth of the fungal pathogens. The diameter of the fungal colonies in poisoned plates was lesser when compared to control plates and it indicates the antifungal effect of cow urine. Maximum inhibition was shown against Fusarium oxysporum (78.57\%) followed by Rhizoctonia solani $(78.37 \%)$ and Sclerotium rolfsii $(73.84 \%)$, whereas minimum inhibition was recorded with 5 percent concentration of cow urine in Rhizoctonia solani $(48.60 \%)$ followed by Fusarium oxysporum (54.76\%) and Sclerotium rolfsii (55.38\%) (Figures 1(a)-1(c)).
Pot culture studies were carried out to find out the effects of cow urine spray on the phenotypic characters of Trigonella foenum-graecum (Methi) (Figure 2) and Abelmoschus esculentus (Bhindi) after 25 days (Figure 3). Parameters such as plant height, shoot length and root length, number of leaves, and leaf length and breadth were observed in the experimental and control plants. It is clear from the results (Tables 2 and 3) that plant height of Methi increased with increase in concentration of cow urine and duration of time. Maximum plant height of Methi was $14.30 \pm 0.40 \mathrm{~cm}$ with maximum concentration, that is, $5 \%$ of cow urine. Plant height of Bhindi plants consistently increased to a maximum of $13.97 \pm 0.50 \mathrm{~cm}$ in the plants treated with $5 \%$ concentration of cow urine; this was followed by the $12.03 \pm 0.42 \mathrm{~cm}$ in $4 \%$ concentration of cow urine. The mean height of Methi plants was $9.00 \pm 0.46 \mathrm{~cm}$ in control plants. Shoot length of Methi was $7.27 \pm 0.25,7.97 \pm 0.25,9.17 \pm 0.31,9.67 \pm 0.25$, and $10 \pm$ $0.20 \mathrm{~cm}$ when sprayed with $1,2,3,4$, and $5 \%$ concentration of cow urine, respectively. Shoot length in control pot was $6.8 \pm$ $0.30 \mathrm{~cm}$. Maximum shoot length and root length of Bhindi plants were $7.83 \pm 0.15$ and $6.20 \pm 0.36 \mathrm{~cm}$ with the plants sprayed with $5 \%$ concentration of cow urine followed by $4 \%$ concentration.

The root length of Methi was maximum $4.13 \pm 0.35 \mathrm{~cm}$ with maximum concentration $(5 \%)$ of cow urine. However, root length increased in all the experimental plants as compared to control. Increase in root length supports the fact that the application of cow urine influences growth by increasing the mitotic index.

The protein content found in seedlings sprayed with cow urine showed more protein irrespective of the concentration as compared to the control (Table 4). The maximum protein content was found in the seedlings of Methi treated with $5 \%$ cow urine, that is, $174.97 \pm 0.50 \mathrm{mg} / \mathrm{mL}$, whereas the control had only $36.50 \pm 0.46 \mathrm{mg} / \mathrm{mL}$ of protein and the seedlings of Bhindi treated with $5 \%$ cow urine contain 164.40 $\pm 0.32 \mathrm{mg} / \mathrm{mL}$ of protein content while the control of Bhindi had only $38.80 \pm 0.46 \mathrm{mg} / \mathrm{mL}$ protein content. Carbohydrate content in 1, 2, 3, 4, and 5\% cow's urine irrigated plant sample of Methi was $144.09 \pm 0.17 \mathrm{mg} / \mathrm{mL}, 162.03 \pm 0.56 \mathrm{mg} / \mathrm{mL}$, 


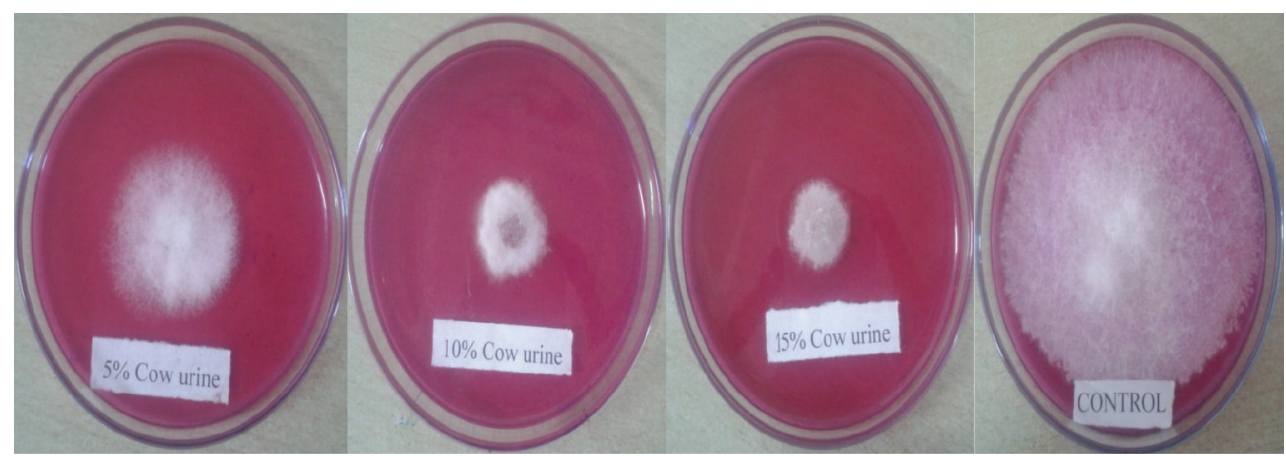

(a)

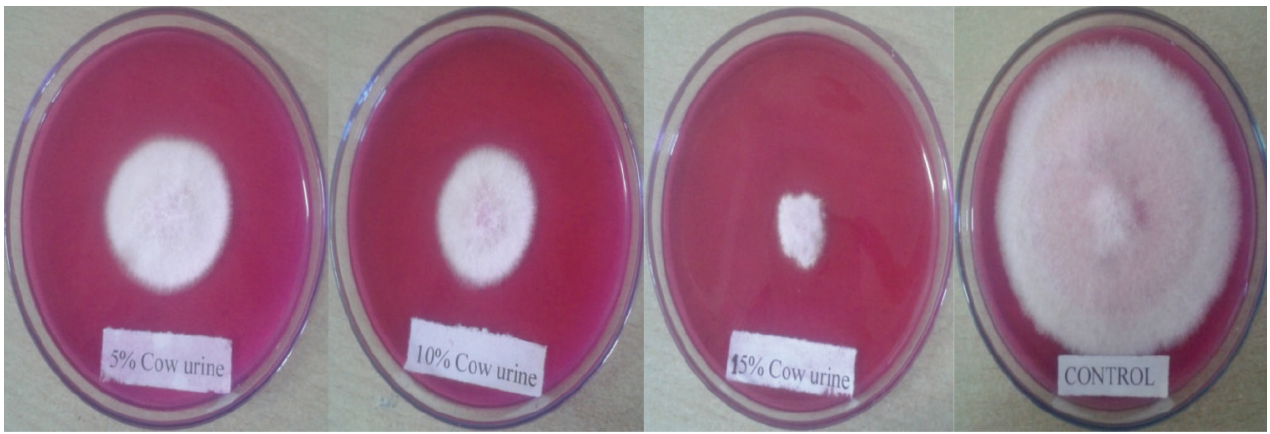

(b)

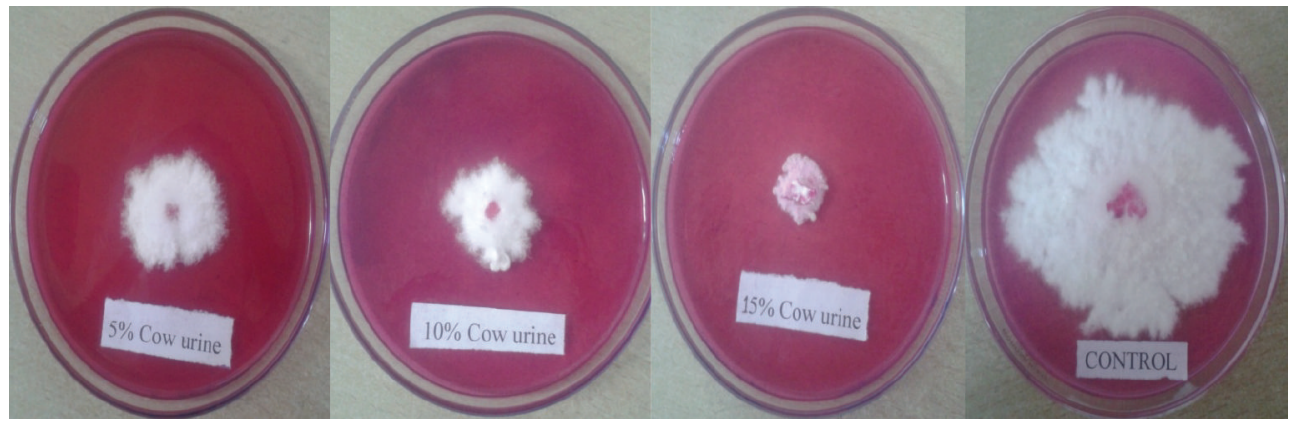

(c)

FIGURE 1: (a) Effect of different concentrations (5\%,10\%, and 15\%) of cow urine on Fusarium oxysporum. (b) Effect of different concentrations $(5 \%, 10 \%$, and $15 \%)$ of cow urine on Rhizoctonia solani. (c) Effect of different concentrations (5\%, 10\%, and 15\%) of cow urine on Sclerotium rolfsii.

TABLE 2: Effect of cow urine on exomorphological characters of Trigonella foenum-graecum (Methi) by pot culture experiment after 25 days.

\begin{tabular}{lccccccc}
\hline $\begin{array}{l}\text { Conc. of } \\
\text { cow urine } \\
(\%)\end{array}$ & $\begin{array}{c}\text { Plant height } \\
(\mathrm{cm})\end{array}$ & $\begin{array}{c}\text { Root length } \\
(\mathrm{cm})\end{array}$ & $\begin{array}{c}\text { Shoot length } \\
(\mathrm{cm})\end{array}$ & $\begin{array}{c}\text { Number of } \\
\text { leaves }\end{array}$ & $\begin{array}{c}\text { Number of } \\
\text { branches }\end{array}$ & $\begin{array}{c}\text { Leaf length } \\
(\mathrm{cm})\end{array}$ & $\begin{array}{c}\text { Leaf breadth } \\
(\mathrm{cm})\end{array}$ \\
\hline 1 & $10.23 \pm 0.75$ & $2.97 \pm 0.50$ & $7.27 \pm 0.25$ & $7.00 \pm 1.00$ & $4.67 \pm 0.58$ & $0.90 \pm 0.26$ & $0.57 \pm 0.15$ \\
2 & $11.17 \pm 0.65$ & $3.20 \pm 0.40$ & $7.97 \pm 0.25$ & $9.33 \pm 0.58$ & $6.00 \pm 1.00$ & $1.13 \pm 0.25$ & $0.73 \pm 0.12$ \\
3 & $12.70 \pm 0.66$ & $3.50 \pm 0.36$ & $9.17 \pm 0.31$ & $11.00 \pm 1.00$ & $6.67 \pm 0.58$ & $1.57 \pm 0.25$ & $1.23 \pm 0.35$ \\
4 & $13.43 \pm 0.75$ & $3.77 \pm 0.31$ & $9.67 \pm 0.25$ & $12.33 \pm 0.58$ & $8.00 \pm 0.00$ & $1.83 \pm 0.12$ & $1.53 \pm 0.38$ \\
5 & $14.30 \pm 0.40$ & $4.13 \pm 0.35$ & $10.00 \pm 0.20$ & $14.00 \pm 1.00$ & $8.33 \pm 0.58$ & $1.97 \pm 0.15$ & $1.73 \pm 0.21$ \\
Control & $9.00 \pm 0.46$ & $2.13 \pm 0.25$ & $6.80 \pm 0.30$ & $6.67 \pm 0.58$ & $4.00 \pm 0.00$ & $0.90 \pm 0.20$ & $0.40 \pm 0.10$ \\
$\mathrm{CD}(0.05)$ & 0.096 & 0.056 & 0.031 & 0.290 & 0.267 & 0.066 \\
\hline
\end{tabular}


TABLE 3: Effect of cow urine on exomorphological characters of Abelmoschus esculentus (Bhindi) by pot culture experiment after 25 days.

\begin{tabular}{lccccccc}
\hline $\begin{array}{l}\text { Conc. of cow } \\
\text { urine }(\%)\end{array}$ & $\begin{array}{c}\text { Plant height } \\
(\mathrm{cm})\end{array}$ & $\begin{array}{c}\text { Root length } \\
(\mathrm{cm})\end{array}$ & $\begin{array}{c}\text { Shoot length } \\
(\mathrm{cm})\end{array}$ & $\begin{array}{c}\text { Number of } \\
\text { leaves }\end{array}$ & $\begin{array}{c}\text { Number of } \\
\text { branches }\end{array}$ & $\begin{array}{c}\text { Leaf length } \\
(\mathrm{cm})\end{array}$ & $\begin{array}{c}\text { Leaf breadth } \\
(\mathrm{cm})\end{array}$ \\
\hline 1 & $8.33 \pm 0.51$ & $1.87 \pm 0.29$ & $6.47 \pm 0.25$ & $1.67 \pm 0.58$ & $1.33 \pm 0.58$ & $1.63 \pm 0.21$ & $1.43 \pm 0.31$ \\
2 & $10.23 \pm 0.57$ & $3.27 \pm 0.35$ & $6.97 \pm 0.23$ & $2.00 \pm 0.00$ & $2.00 \pm 0.00$ & $1.80 \pm 0.26$ & $1.47 \pm 0.31$ \\
3 & $11.27 \pm 0.50$ & $3.93 \pm 0.25$ & $7.33 \pm 0.25$ & $2.00 \pm 1.00$ & $2.67 \pm 0.58$ & $2.17 \pm 0.25$ & $1.90 \pm 0.20$ \\
4 & $12.03 \pm 0.42$ & $4.50 \pm 0.17$ & $7.50 \pm 0.30$ & $2.67 \pm 0.58$ & $3.00 \pm 0.00$ & $2.40 \pm 0.36$ & $2.17 \pm 0.25$ \\
5 & $13.97 \pm 0.50$ & $6.20 \pm 0.36$ & $7.83 \pm 0.15$ & $3.00 \pm 0.00$ & $3.00 \pm 0.00$ & $2.77 \pm 0.25$ & $2.40 \pm 0.26$ \\
Control & $6.50 \pm 0.46$ & $1.67 \pm 0.31$ & $4.80 \pm 0.20$ & $1.33 \pm 0.58$ & $1.67 \pm 0.58$ & $1.23 \pm 0.31$ & $0.97 \pm 0.25$ \\
$\mathrm{CD}(0.05)$ & 0.068 & 0.069 & 0.046 & 0.367 & 0.242 & 0.035 & 0.038 \\
\hline
\end{tabular}

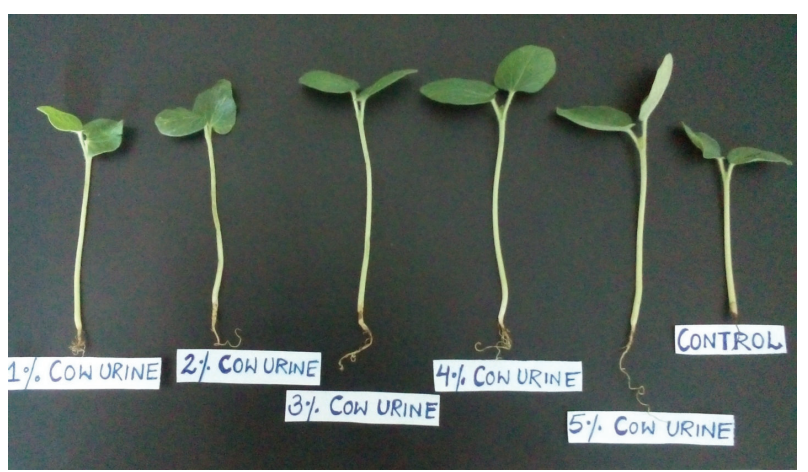

Figure 2: Effect of different concentrations (1\%, 2\%, 3\%, 4\%, and $5 \%$ ) of cow urine on Trigonella foenum-graecum (Methi) after 25 days.

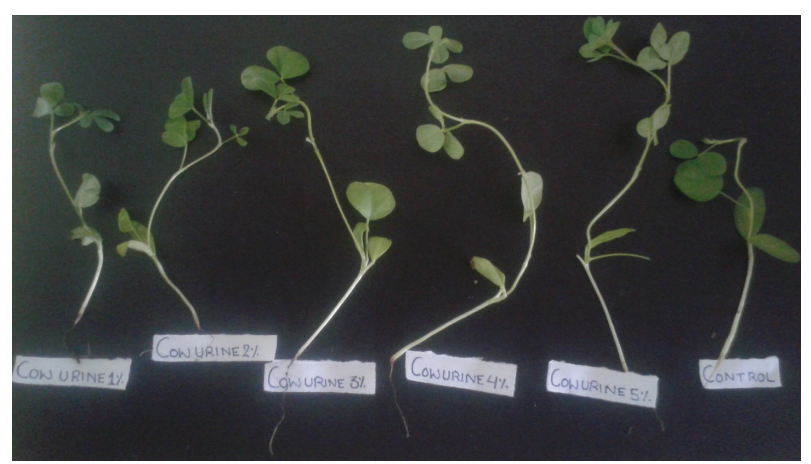

Figure 3: Effect of different concentrations (1\%,2\%,3\%, 4\%, and 5\%) of cow urine on Abelmoschus esculentus (Bhindi) after 25 days.

$187.07 \pm 0.23 \mathrm{mg} / \mathrm{mL}, 188.93 \pm 0.78 \mathrm{mg} / \mathrm{mL}$, and $194.40 \pm$ $0.27 \mathrm{mg} / \mathrm{mL}$, respectively, and the carbohydrate content in $1,2,3,4$, and 5\% cow's urine irrigated plant sample of Bhindi was $44.03 \pm 0.11 \mathrm{mg} / \mathrm{mL}, 62.33 \pm 0.17 \mathrm{mg} / \mathrm{mL}, 97.07 \pm$ $0.59 \mathrm{mg} / \mathrm{mL}, 123.93 \pm 0.12 \mathrm{mg} / \mathrm{mL}$, and $164.40 \pm 0.32 \mathrm{mg} / \mathrm{mL}$, respectively (Table 5). However, the carbohydrate content in control plants of Methi and Bhindi was $138.80 \pm 0.89 \mathrm{mg} / \mathrm{mL}$ and $134.20 \pm 0.90 \mathrm{mg} / \mathrm{mL}$, respectively.

The chlorophyll content of Methi and Bhindi (Okra) is shown in Table 6. The total chlorophyll content of Trigonella foenum-graecum (Methi) was recorded more in plant leaves irrigated with $5 \%$ cow urine. It had $0.972 \pm 3 \mathrm{mg} / \mathrm{g}$ of
TABle 4: Protein estimation of Trigonella foenum-graecum (Methi) and Abelmoschus esculentus (Bhindi) sprayed with different concentrations of cow urine.

\begin{tabular}{lccc}
\hline \multirow{2}{*}{ S. number Conc. of cow urine $(\mathrm{v} / \mathrm{v} \%)$} & \multicolumn{2}{c}{ Protein $(\mathrm{mg} / \mathrm{mL})$} \\
& & Methi & Bhindi \\
\hline 1 & 1 & $42.33 \pm 0.51$ & $44.03 \pm 0.11$ \\
2 & 2 & $50.23 \pm 0.57$ & $62.33 \pm 0.17$ \\
3 & 3 & $71.27 \pm 0.50$ & $97.07 \pm 0.59$ \\
4 & 4 & $103.03 \pm 0.42$ & $123.93 \pm 0.12$ \\
5 & 5 & $174.97 \pm 0.50$ & $164.40 \pm 0.32$ \\
6 & Control & $36.50 \pm 0.46$ & $38.80 \pm 0.46$ \\
& CD & $0.168 \pm 0.11$ & $0.271 \pm 0.12$ \\
\hline
\end{tabular}

TABle 5: Carbohydrate estimation of Trigonella foenum-graecum (Methi) and Abelmoschus esculentus (Bhindi) sprayed with different concentrations of cow urine.

\begin{tabular}{lccc}
\hline \multirow{2}{*}{ S. number Conc. of cow urine (\%) } & \multicolumn{2}{c}{ Carbohydrate $(\mathrm{mg} / \mathrm{mL})$} \\
Methi & Bhindi \\
\hline 1 & 1 & $144.09 \pm 0.17$ & $145.07 \pm 0.17$ \\
2 & 2 & $162.03 \pm 0.56$ & $162.03 \pm 0.56$ \\
3 & 3 & $187.07 \pm 0.23$ & $177.07 \pm 0.23$ \\
4 & 4 & $188.93 \pm 0.78$ & $180.09 \pm 0.78$ \\
5 & 5 & $194.40 \pm 0.27$ & $184.60 \pm 0.12$ \\
6 & Control & $138.80 \pm 0.89$ & $134.20 \pm 0.90$ \\
\hline
\end{tabular}

chlorophyll a, $0.897 \pm 96 \mathrm{mg} / \mathrm{g}$ of chlorophyll b, and $1.869 \pm$ $21 \mathrm{mg} / \mathrm{g}$ of total chlorophyll. Control plants had $0.437 \pm$ $71 \mathrm{mg} / \mathrm{g}$ of total chlorophyll. The total chlorophyll content in Abelmoschus esculentus (Bhindi) leaves was maximum with $5 \%$ cow urine irrigation $(2.246 \pm 28 \mathrm{mg} / \mathrm{g})$ followed by $4 \%(1.599 \pm 88 \mathrm{mg} / \mathrm{g}), 3 \%(0.803 \pm 98 \mathrm{mg} / \mathrm{g}), 2 \%(0.690 \pm$ $44 \mathrm{mg} / \mathrm{g})$, and $1 \%(0.544 \pm 2 \mathrm{mg} / \mathrm{g})$. The control of Bhindi plants had $0.146 \pm 66 \mathrm{mg} / \mathrm{g}$ of chlorophyll a, $0.025 \pm 8 \mathrm{mg} / \mathrm{g}$ of chlorophyll b, and $0.171 \pm 91 \mathrm{mg} / \mathrm{g}$ of total chlorophyll.

\section{Discussion}

This study revealed that the cow urine at different concentrations had considerable effect on the vegetative growth of $R$. stolonifer, Sclerotium rolfsii, and F. oxysporum. It is clear from the results that 15 percent concentration of cow 
TABle 6: Chlorophyll estimation of Trigonella foenum-graecum (Methi) and Abelmoschus esculentus (Bhindi) sprayed with different concentrations of cow urine.

\begin{tabular}{|c|c|c|c|c|c|c|c|}
\hline \multirow{3}{*}{ S. number } & \multirow{3}{*}{ Conc. of cow urine } & \multicolumn{6}{|c|}{ Chlorophyll (mg/g) } \\
\hline & & \multicolumn{3}{|c|}{ Methi } & \multicolumn{3}{|c|}{ Bhindi } \\
\hline & & $\begin{array}{c}\text { Chlorophyll } \\
\mathrm{a}\end{array}$ & $\begin{array}{c}\text { Chlorophyll } \\
\text { b }\end{array}$ & $\begin{array}{c}\text { Total } \\
\text { chlorophyll } \\
\end{array}$ & $\begin{array}{c}\text { Chlorophyll } \\
\mathrm{a}\end{array}$ & $\begin{array}{c}\text { Chlorophyll } \\
\text { b }\end{array}$ & $\begin{array}{c}\text { Total } \\
\text { chlorophyll } \\
\end{array}$ \\
\hline 1 & 1 & $0.407 \pm 17$ & $0.327 \pm 12$ & $0.733 \pm 09$ & $0.368 \pm 27$ & $0.176 \pm 01$ & $0.544 \pm 02$ \\
\hline 2 & 2 & $0.451 \pm 09$ & $0.365 \pm 80$ & $0.816 \pm 38$ & $0.449 \pm 81$ & $0.241 \pm 07$ & $0.690 \pm 44$ \\
\hline 3 & 3 & $0.563 \pm 87$ & $0.466 \pm 63$ & $1.029 \pm 92$ & $0.502 \pm 43$ & $0.301 \pm 30$ & $0.803 \pm 98$ \\
\hline 4 & 4 & $0.922 \pm 23$ & $0.738 \pm 07$ & $1.660 \pm 02$ & $0.996 \pm 18$ & $0.603 \pm 08$ & $1.599 \pm 88$ \\
\hline 5 & 5 & $0.972 \pm 03$ & $0.897 \pm 96$ & $1.869 \pm 21$ & $1.404 \pm 92$ & $0.842 \pm 02$ & $2.246 \pm 28$ \\
\hline 6 & Control & $0.248 \pm 28$ & $0.189 \pm 10$ & $0.437 \pm 71$ & $0.146 \pm 66$ & $0.025 \pm 08$ & $0.171 \pm 91$ \\
\hline
\end{tabular}

urine showed maximum inhibition in growth of all the three fungal pathogens as compared to control. Inhibitory activity of cow urine against fungal pathogens have been reported by different workers $[8,15,16]$. Pot culture studies revealed that increase in cow urine concentrations increased the performance of all phenotypic characters of Methi and Bhindi. Present studies are in accordance with the findings of [17] Oliveira et al. 2009 who reported that the increase in cow urine concentrations increased the performance of all lettuce characteristics like fresh and dry leaf mass, fresh and dry stem mass, stem length, fresh root mass, fresh head mass, and commercial yield. The work of [18] Tharmaraj, 2011, reported that growth substances in panchagavya help to bring rapid changes in phenotypes of plants and also improve the growth and productivity. The protein and carbohydrate content found in seedlings sprayed with cow urine was more irrespective of the concentration as compared to the control. The biochemical contents (carbohydrates, protein, and amino acids) in Abelmoschus esculentus (L.) Moench and Vigna mungo increased with $3 \%$ concentration of panchagavya spray $[8,19]$. It is evident from the results that the chlorophyll content of Methi and Bhindi plants increased with increase in concentration of cow urine. Similar findings with panchagavya spray were observed in Arachis hypogaea [20] and Abelmoschus esculentus (L.) Moench [8].

\section{Conclusion}

It was revealed from the study that cow urine caused inhibition in growth of all the three fungal pathogens used in the present studies. This demonstrated fungitoxic potential of cow urine against the three pathogenic fungi. The biochemical contents of both the plants increased when sprayed with cow urine. Therefore the use of cow urine provides better alternative to synthetic chemicals which are expensive and pose potential danger to the farmers, marketers, consumers, and environment. The cow urine can be used as biopesticide.

\section{Conflict of Interests}

The authors declare that they have no conflict of interests.

\section{Acknowledgment}

Authors are thankful to Department of Microbiology, Shoolini Institute of Life Sciences and Business Management, for offering facilities to carry out this work.

\section{References}

[1] A. Sathasivam, M. Muthuselvam, and R. Rajendran, "Antimicrobial activities of cow urine distillate against some clinical pathogens," Global Journal of Pharmacology, vol. 4, no. 1, pp. 4144, 2010.

[2] M. L. Pathak and A. Kumar, "Cow praising and importance of Panchyagavya as medicine," Sachitra Ayurveda, vol. 5, pp. 5659, 2003.

[3] R. Chauhan, B. P. Singh, and L. K. Singhal, "Immunomodulation with kamdhenu Ark in mice," Journal of Immunology and Immunopathology, vol. 71, pp. 89-92, 2001.

[4] H. Bhadauria, "Cow urine- a magical therapy. Vishwa Ayurveda Parishad," International Journal of Cow Science, vol. 1, pp. 32-36, 2002.

[5] K. Dharma, R. Rajesh, R. S. Chauhan, and T. Simmi, "Panchgavya (Cowpathy): an overview," International Journal of Cow Science, vol. 1, no. 1, pp. 1-15, 2005.

[6] S. A. Mandavgane, A. K. Rambhal, and N. K. Mude, "Development of cow urine based disinfectant," Natural Product Radiance, vol. 4, pp. 410-412, 2005.

[7] K. Krishnamurthi, D. Dutta, S. D. Sivanesan, and T. Chakrabarti, "Protective effect of distillate and redistillate of cow's urine in human polymorphonuclear leukocytes challenged with established genotoxic chemicals," Biomedical and Environmental Sciences, vol. 17, no. 3, pp. 247-256, 2004.

[8] M. Rajesh and K. Jayakumar, "Changes in morphological, biochemical and yield parameters of Abelmoschus esculents (L.) Moench due to panchagavya spray," International Journal of Modern Plant \& Animal Sciences, vol. 1, no. 2, pp. 82-95, 2013.

[9] K. N. Rakesh, N. Dileep, N. A. S. Nawaz, S. Junaid, and P. T. R. Kekuda, "Antifungal activity of cow urine against fungal pathogens causing rhizome rot of ginger," Environment and Ecology, vol. 31, no. 3, pp. 1241-1244, 2013.

[10] O. D. Dhingra and A. C. Kapoor, "Nutritive value of mango seed kernel," Journal of the Science of Food and Agriculture, vol. 36, no. 8, pp. 752-756, 1985.

[11] J. M. Vincent, "Distortion of fungal hyphæ in the presence of certain inhibitors," Nature, vol. 159, no. 4051, p. 850, 1947. 
[12] M. M. Bradford, "A rapid and sensitive method for the quantitation of microgram quantities of protein utilizing the principle of protein-dye binding," Analytical Biochemistry, vol. 72, no. 1-2, pp. 248-254, 1976.

[13] J. E. Hedge and B. T. Hofreiter, "Determination of total carbohydrates by anthrone," in Carbohydrate Chemistry, R. L. Whistler and J. N. Be Miller, Eds., p. 420, Academic Press, New York, NY, USA, 1962.

[14] D. I. Arnon, "Copper enzymes in isolated chloroplasts. Polyphenoloxidase in Beta vulgaris," Plant Physiology, vol. 24, no. 1, pp. $1-15,1949$.

[15] A. B. Basak, M. W. Lee, and T. S. Lee, "Inhibitive activity of cow urine and cow dung against Sclerotinia sclerotiorum of cucumber," Mycobiology, vol. 30, no. 3, pp. 175-179, 2002.

[16] K. N. Rakesh, N. Dileep, S. Junaid, K. T. R. Prashith, K. S. Vinayaka, and N. A. S. Noor, "Inhibitory effect of cow urine extracts of selected plants against pathogens causing rhizome rot of ginger," Science, Technology and Arts Research Journal, vol. 2, no. 2, pp. 92-96, 2013.

[17] N. L. Oliveira, M. Puiatti, R. H. S. Santos, P. R. Cecon, and P. H. R. Rodrigues, "Soil and leaf fertilization of lettuce crop with cow urine," Horticultura Brasileirae, vol. 27, pp. 102-536, 2009.

[18] K. Tharmaraj, P. Ganesh, R. Suresh Kumar, A. Anandan, and K. Kolanjinathan, "A critical review on Panchagavya-a boon plant growth," International Journal of Pharmaceutical and Biological Archive, vol. 2, no. 6, pp. 1611-1614, 2011.

[19] S. L. Chopra and J. S. Kunwar, "Effect of panchagavya on growth of Oryza sativa," in Analytical Agricultural Chemistry, pp. 180244, Kalyan Publishers, New Delhi, India, 1976.

[20] A. Subramaniyan, "Effect of Panchagavya on Escherichia coli in procured milk," Indian Veterinary Journal, vol. 82, pp. 799-800, 2005. 


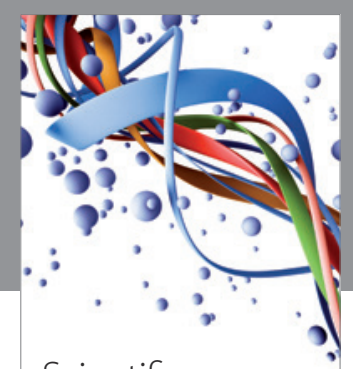

Scientifica
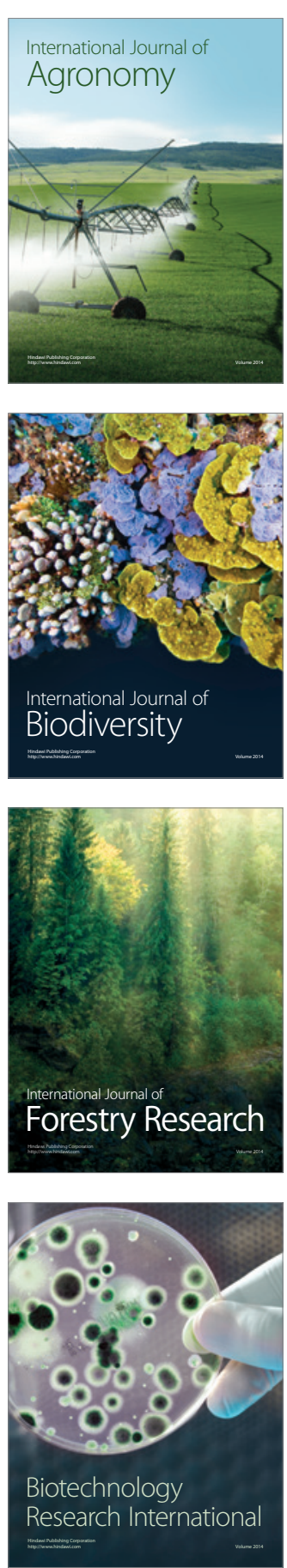
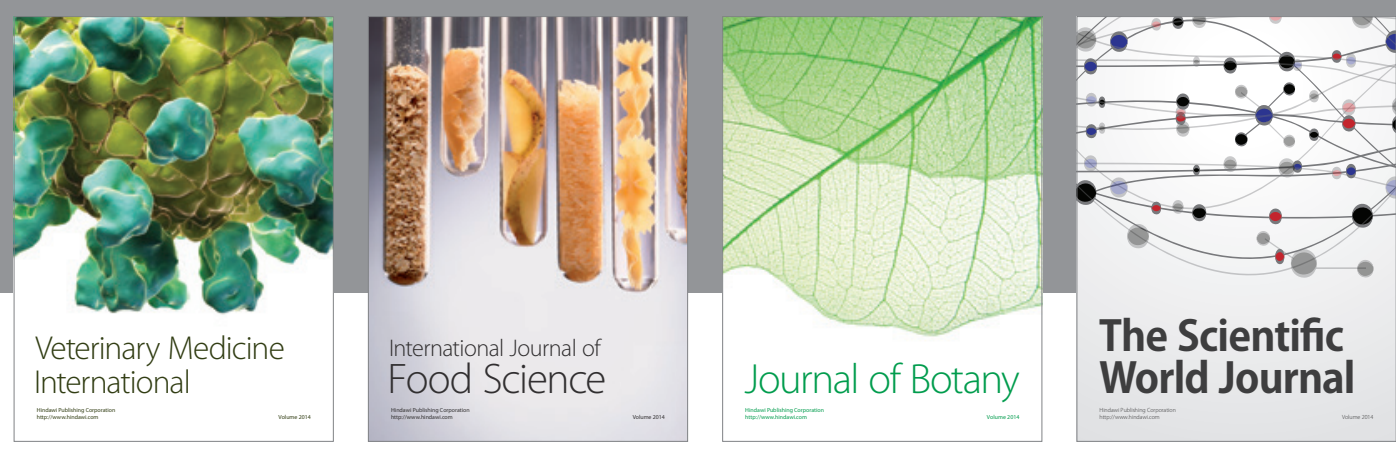

The Scientific World Journal
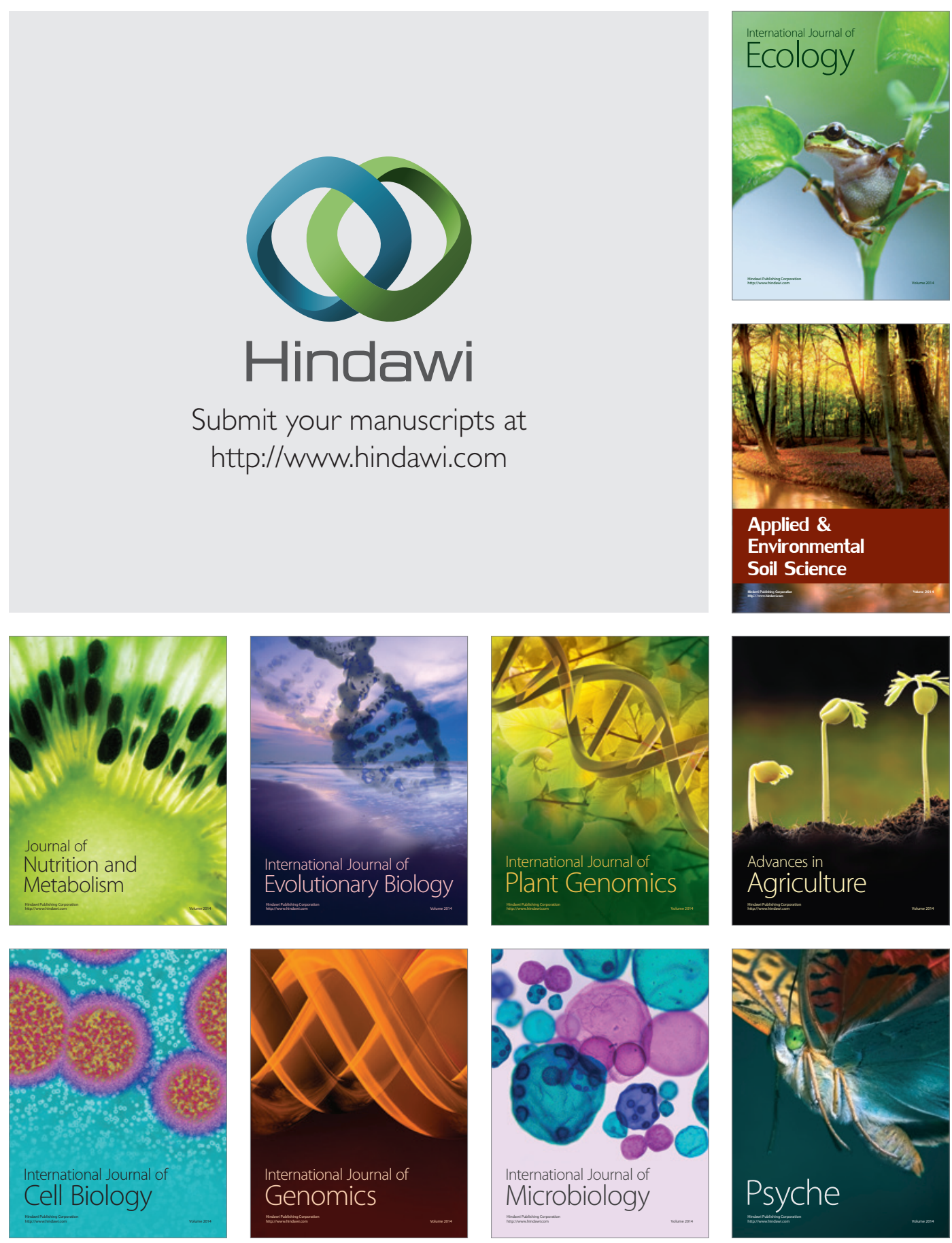